\title{
Australia Antigen and Antibody in Transfused Children with Thalassaemia*
}

\author{
A. VIERUCCI, W. T. LONDON, B. S. BLUMBERG, A. I. SUTNICK, and \\ F. RAGAZZINI \\ From the Institute for Cancer Research, Fox Chase, Philadelphia, Pennsylvania, U.S.A.; and the Paediatric Clinic, \\ University of Florence, Italy
}

\begin{abstract}
Vierucci, A., London, W. T., Blumberg, B. S., Sutnick, A. I., and Ragazzini (1972). Archives of Disease in Childhood, 47, 760. Australia antigen and antibody in transfused children with thalassaemia. As a consequence of frequent transfusions, $10 \%$ of 169 Italian patients with thalassaemia developed $\mathrm{Au}(1)$ and $20 \%$ anti-Au(1). $\mathrm{Au}(1)$ persisted in the children in whom it was detected for the duration of the study (2-7 years) or until the patient died. Anti-Au(1) was less persistent.

In these children, $\mathrm{Au}(1)$ or anti-Au(1) was detected, but not both, suggesting that patients with persistent $\mathrm{Au}(1)$ and antibody formers represent two distinct subgroups of the thalassaemia population. $\mathrm{Au}(1)$ was more common in males and in patients less than 7 years old, and was associated with earlier death; whereas antibody was more common in females, and in children older than 7 years, and was associated with longer survival.
\end{abstract}

Australia antigen was discovered as a result of a systematic search for human serum protein polymorphisms (Blumberg, 1964). Epidemiological, morphological, biochemical, and tissue culture data strongly support the hypothesis that Australia antigen $\mathrm{Au}(1)$ is (or is located on) an infectious agent which can cause hepatitis in man (Sutnick, London, and Blumberg, 1967; Blumberg, Sutnick, and London, 1970c; Shulman, Hirschman, and Barker, 1970; Gerin et al., 1969).

In acute viral hepatitis $\mathrm{Au}(1)$ appears early in the disease, often before any clinical signs or symptoms, lasts a few days or weeks, and then becomes undetectable. Some people, however, are chronic carriers of $\mathrm{Au}(1)$. They have little or no evidence of liver disease but transfusion of their blood can transmit hepatitis to recipients. Studies have shown that 1 to $20 \%$ of apparently normal persons among certain (mostly tropical) populations have $\mathrm{Au}(1)$ in their blood (Blumberg et al., 1970c). Family studies by our group and in Ceppellini's laboratory (Ceppellini et al., 1970) are compatible with the hypothesis that suscepti-

Received 16 March 1972.

*Supported in part by USPHS Grants CA-06551, CA-06927, and RR-O5539 from the National Institutes of Health and by an appropriation from the Commonwealth of Pennsylvania. bility to become an $\mathrm{Au}(1)$ carrier is inherited as an autosomal recessive trait.

On systematic follow-up studies of 189 recipients of $\mathrm{Au}(1)$ blood, 131 developed hepatitis (as denoted by serum glutamic pyruvic transaminase (SGPT) elevation), 65 developed Australia antigen, and 29 antibody to Australia antigen. Of 345 recipients of only Australia antigen negative blood, 93 developed SGPT elevation, 14 developed $\mathrm{Au}(1)$, and 2 anti-Au(1). Some of the people who developed $\mathrm{Au}(1)$ or anti-Au(1) had no apparent clinical illness. Thus, the recipient of blood containing $\mathrm{Au}(1)$ is likely to develop hepatitis, $\mathrm{Au}(1)$, or anti-Au(1) (Goeser et al., 1970; Okochi et al., 1970; Gocke, Greenberg, and Kavey, 1970; Goldfield, 1970).

Anti-Au(1) antibodies (detected by immunodiffusion) have been found primarily in sera from transfused patients with haemophilia, aplastic anaemia, and thalassaemia. They have also been detected in patients who have never been transfused; some of these have had clinical hepatitis, but others have had no apparent illness. The observations are consistent with the hypothesis that antibodies form in patients 'infected' with $\mathrm{Au}(1)$ either by transfusion or by other routes. The frequency of anti-Au(1) antibodies in sera from thalassaemic 
patients was much lower $(2 \cdot 1 \%)$ than in sera from haemophiliac patients $(28.6 \%)$ (Blumberg, Alter, and Visnich, 1965), perhaps because the patients with haemophilia received fresh frozen plasma, whereas the patients with thalassaemia received packed red cells and whole blood.

We have found that there is an enormous variation in host response to infection, including the development of acute viral hepatitis, chronic and persistent active hepatitis, chronic anicteric hepatitis, and chronic infection (carrier state) with $\mathrm{Au}(1)$ without evidence of hepatitis (Blumberg et al., 1970c). From this it is clear that host factors must be taken into account in evaluating the effects of transfusion.

In this paper we present results of a study of patients with thalassaemia living in northern Italy who have received large numbers of transfusions. This investigation has the epidemiological advantage that there is no problem of sampling; the entire sample group is included and the follow-up is nearly complete. We report our observations on the occurrence of $\mathrm{Au}(1)$ and anti- $\mathrm{Au}(1)$ antibody in 169 patients with thalassaemia. An average of three serum samples was tested annually during a period of 2 to 7 years. The largest number was 20 . Age, sex, immunoglobulin levels, mortality rate, and splenectomy have been considered in their possible relation to the presence of $\mathrm{Au}(1)$ antigen and antibody.

\section{Materials and Methods}

A total of 3180 specimens from 169 thalassaemic patients collected over a 7-year period were studied. These patients included 143 from the Centro della Microcitemia of Ferrara; 21 from the Paediatric Clinic of the University of Ferrara; 3 from the Paediatric Clinic of the University of Siena; and 2 from the Paediatric Clinic of the University of Florence. This represents essentially the entire thalassaemia population attending these clinics during the period of observation.

\section{Test for Au antigen and antibody.}

(A) Immunodiffusion. The test was carried out in $8 \times 10 \mathrm{~cm}$ plates, in $1.1 \%$ agarose in phosphate buffered saline ( $p \mathrm{H} \mathrm{7.4)} \mathrm{(Blumberg} \mathrm{et} \mathrm{al.,} \mathrm{1970a).} \mathrm{The}$ method of Piazzi (1969) was also employed in the samples collected during 1969 and 1970 to determine the optimal conditions for the antigen/antibody reaction.

(B) Cross-electrophoresis. Australia antigen and antibody were also investigated in the sera collected during 1969 and 1970 by a modification of the reaction electrophoresis method of Lang (1966). $8 \times 10 \mathrm{~cm}$ lantern slides were layered with $1 \%$ agarose $(1.3 \%$ agar noble for the screening of antibodies) in barbitone buffer $p \mathrm{H} 8 \cdot 2,0.05 \mathrm{M}$. Two parallel rows of $2 \mathrm{~mm}$ diameter holes were punched in the gel at a distance of $5 \mathrm{~mm}$ from each other. When the test is used for the detection of $\mathrm{Au}(1)$ antigen, the sera to be tested are placed in the wells punched in the cathodic portions of the slide. Antibody to $\mathrm{Au}(1)$ is placed in each opposite well. When detection of anti-Au(1) is desired, the unknown sera are placed in the anodic part of the slide, and a known positive $A u(1)$ in the opposite wells. A current of 60 volts is then applied to the extremes of the slide, for a period of $\mathbf{7 5}$ minutes.

Quantitation of $\operatorname{Ig} A, \operatorname{IgG}, \operatorname{IgM}$, and $\operatorname{IgD}$. The 18 thalassaemia patients with $\mathrm{Au}(1)$ in their serum were matched by sex in age order with 18 patients with anti$\mathrm{Au}(1)$, and with 18 patients who had not developed either the antigen or the antibody. The age range for most triplets was three years, the maximum range for any triplet was six years. All sera were tested for immunoglobulin levels (IgA, IgG, IgM, IgD) by the method of Mancini, Carbonara, and Heremans, 1965, using commercial immunodiffusion plates (Melpar).

Statistical methods. The immunoglobulin values in the three groups of patients were compared by the Wilcoxon matched pair signed rank test. The relation between mortality, splenectomy, sex, and age, and the distribution of $\mathrm{Au}(1)$ antigen and antibody were tested by the $\chi^{2}$ method, and Fisher's exact test. The sex distribution of $\mathrm{Au}(1)$ and anti- $\mathrm{Au}(1)$ was also evaluated using tests for the difference between two correlated proportions. When a total sample ( $\mathrm{n}$ ) is divided into several categories $\left(x_{1}, x_{2}\right.$, etc.), we can observe the proportions $x_{1} / n=p_{1}, x_{2} / n=p_{2}$, etc. To test the null hypothesis $p_{j}=p_{k}=\vec{p}$, we expect $p_{j}-p_{k}$ to be normally distributed with large enough $n$, and use the

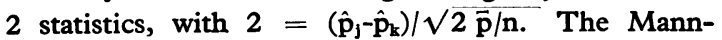
Whitney test was used for evaluating mortality differences between the groups (Siegel, 1956).

\section{Results}

Frequency of $\mathrm{Au}(1)$ and anti-Au(1). Australia antigen was detected in $18(10.6 \%)$ of the 169 thalassaemia children and the antibody in 35 $(20 \cdot 7 \%)$. In one case the antigen was observed before transfusion. The results with cross electrophoresis and the technique of Piazzi (1969) were the same as immunodiffusion, except that (1) antibody was detected in an additional 2 patients ( 35 instead of 33), and (2) in 9 patients, who had had $\mathrm{Au}(1)$ or anti-Au(1) detected by immunodiffusion in early samples; some follow-up samples were positive by cross electrophoresis though negative by immunodiffusion.

Persistence of antigen and antibody. Once present the antigen persisted for the duration of this study ( 2 to 7 years) or until the patient died 
(Fig. 1). The only exception was the failure to detect $\mathrm{Au}(1)$ in patient PT in 1966 and 1968. Follow-up studies of the 35 patients with antibody are shown in Fig. 2. Antibody, in general, was persistent, but in several cases it disappeared, usually to return again. There was one case in which a weak antibody was found in a single sample,

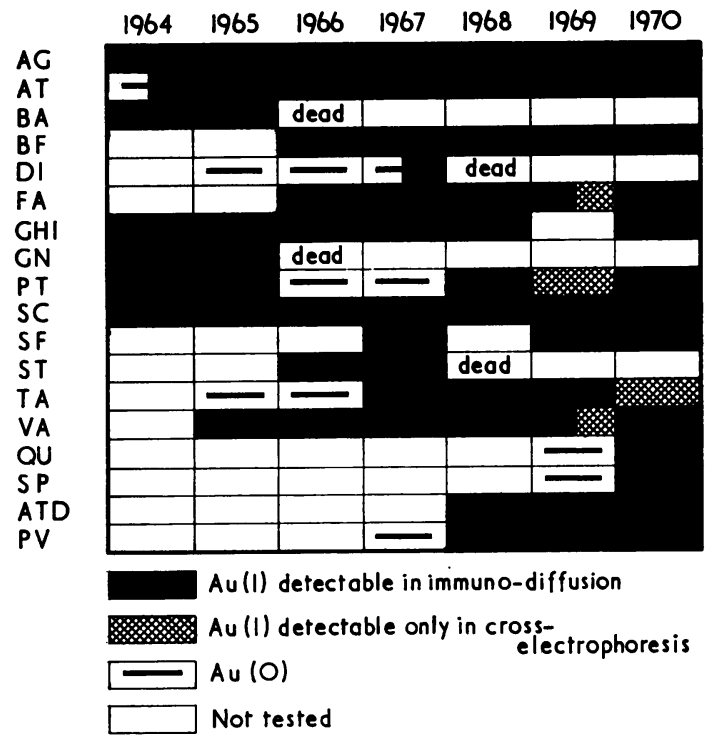

Fig. 1.-Australia antigen in 18 patients with thalassaemia. Initials identify individual patients. $A u(0)=$ absence of Australia antigen.

and antigen was subsequently detected in later samples. Other than this, the thalassaemic children had either antigen or antibody but not both.

Sex, age, mortality, and splenectomy. $\mathrm{Au}(1)$ is more frequent in males $(14.3 \%)$ than in females $(6.4 \%)$ (Table $I)$. This difference is not statistically significant $\left(\chi^{2}=1.972, P>0 \cdot 10\right)$, but it is consistent with findings in other healthy and disease populations (London, Sutnick, and Blumberg, 1969; Sutnick et al., 1968; Blumberg et al., 1970b; Blumberg et al., 1972). Antibody is more frequent in females $(30.0 \%)$ than in males $(22.9 \%)$, but this difference is also not significant $\left(x^{2}=0.26, P>0 \cdot 50\right)$. However, when the differences between two correlated proportions are tested we found that the proportion of females with anti-Au(1) was significantly greater than the proportion of females with $\mathrm{Au}(1)(P=0.00126)$, whereas there was no significant difference between the proportion of males with $\mathrm{Au}(1)$ and those with anti-Au (1).
TABLE I

Distribution of $A u(1)$ Antigen and Anti-Au(1) Antibody in Thalassaemic Children According to Sex

\begin{tabular}{l|c|c|c|c}
\hline \multicolumn{1}{|c|}{ Sex } & $\begin{array}{c}\text { With } \\
\text { Au(1) }\end{array}$ & $\begin{array}{c}\text { With } \\
\text { Anti- } \\
\text { Au(1) }\end{array}$ & $\begin{array}{c}\text { Without } \\
\text { Au(1) or } \\
\text { Anti-Au(1) }\end{array}$ & Total \\
\hline Males & 13 & 17 & 61 & 91 \\
Females & 5 & 18 & 55 & 78 \\
\hline Total & 18 & 35 & 116 & 169
\end{tabular}

Tests for the difference between two correlated proportions:

(a) Proportion of males with $\mathrm{Au}(1)$ vs. proportion of males with anti-Au(1) $z=0.732 \mathrm{P}=0.76$, n.s.

(b) Proportion of females with $\mathrm{Au}(1)$ vs. proportion of females with anti-Au(1) $\mathrm{z}=-3.02 \mathrm{P}=0.00126$

(c) Proportion of both males and females with $\mathrm{Au}(1)$ vs. proportion of both with anti- $\mathrm{Au}(1)$ $z=-2.37 \mathrm{P}=0.0176$

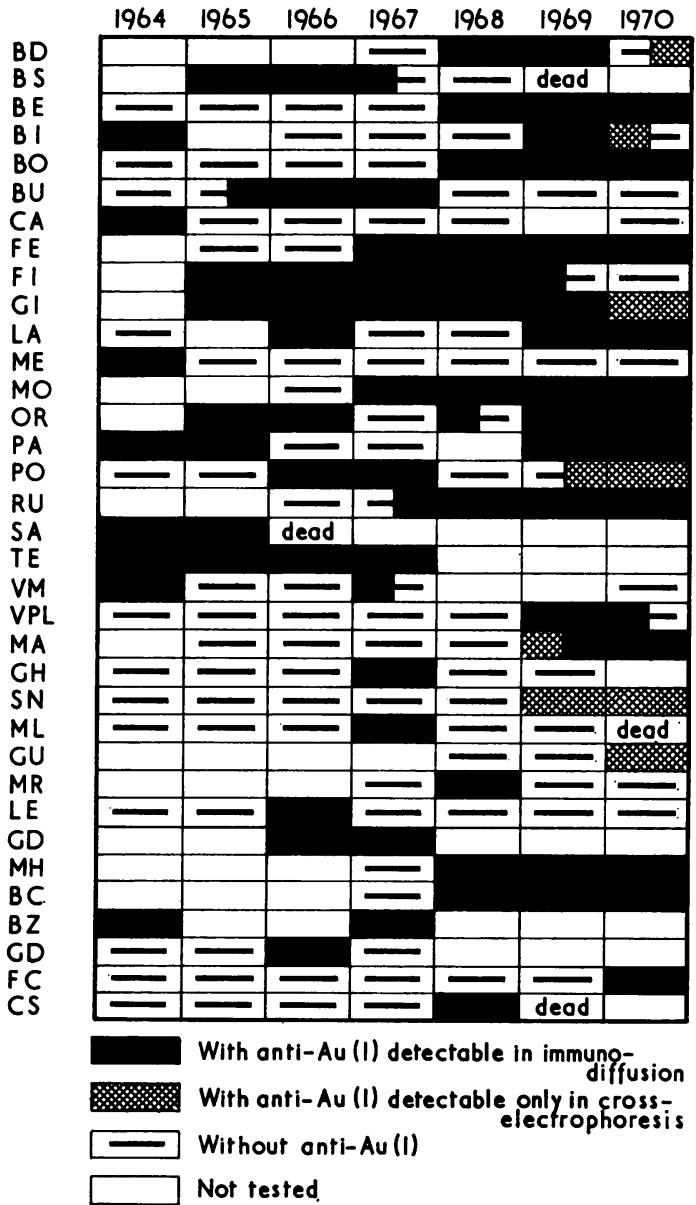

Fig. 2.-Antibody to Australia antigen in 35 patients with thalassaemia. Initials identify individual patients. 
The average life span of patients with thalassaemia is 15 years. In order to determine the relation of age to the presence of $\mathrm{Au}(1)$ antigen and antibody, the study group was divided into those less than 7 years and those greater than 7 years (Table II).

\section{TABLE II}

Distribution of $A u(1)$ Antigen and Anti-Au(1) Antibodies in Thalassaemic Children Divided in Two Groups According to Age

\begin{tabular}{l|c|c|c|c}
\hline \multicolumn{1}{c|}{ Age } & $\begin{array}{c}\text { With } \\
\mathrm{Au}(1)\end{array}$ & $\begin{array}{c}\text { With } \\
\text { Anti- } \\
\mathrm{Au}(1)\end{array}$ & $\begin{array}{c}\text { Without } \\
\mathrm{Au}(1) \text { or } \\
\text { Anti-Au(1) }\end{array}$ & Total \\
\hline$<7 \mathrm{yr}$ & 10 & 6 & 61 & 77 \\
$>7 \mathrm{yr}$ & 8 & 29 & 55 & 92 \\
\hline Total & 18 & 35 & 116 & 169 \\
\hline
\end{tabular}

$\mathrm{Au}(1)$ vs. anti- $\mathrm{Au}(1)$ with respect to age: $\chi^{2}=14 \cdot 428, \mathrm{P}<0 \cdot 001$.

\section{TABLE III}

Distribution of $A u(1)$ and $A n t i-A u(1)$ in Thalassaemic Children by Age at First Blood Transfusion (Reliable data only)

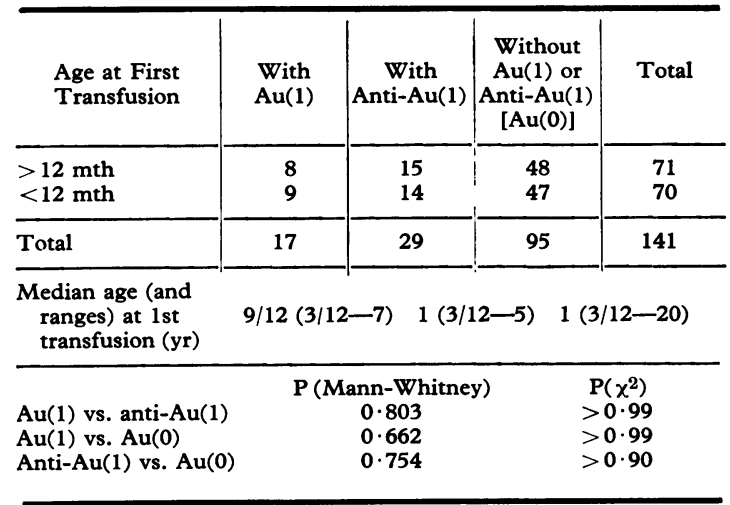

There is a higher frequency of antibody in the older patients and a higher frequency of antigen in the younger ones, and this joint difference is significant $\left(x^{2}=17 \cdot 410, P<0.001\right)$. At the time of the first blood transfusion, there were no differences between the ages of the patients who eventually developed $\mathrm{Au}(1)$, and anti-Au(1), or neither (Table III).

The mortality rate during the 7-year study period in patients with $\mathrm{Au}(1)$, and anti-Au(1) and with neither is shown in Table IV. It is higher in the patients with $\mathrm{Au}(1)(22 \cdot 2 \%)$ than in those of the other groups (anti-Au(1) $=11 \cdot 4 \%$, neither $\mathrm{Au}(1)$ nor anti-Au(1) $=9.5 \%)$, and the median age at death is younger $(\mathrm{Au}(1)=5$ years, anti- $\mathrm{Au}(1)$ $=10.5$ years, neither $\mathrm{Au}(1)$ nor anti-Au(1) $=7$ years). However, the longer survival among the patients with anti-Au(1) is significant compared with the patients with $\operatorname{Au}(1)(P=0.014)$, and is marginally significant compared with those without antigen or antibody $(P=0.086)$.

The relation of splenectomy to $\mathrm{Au}(1)$ and anti$\mathrm{Au}(1)$ is shown in Table $\mathrm{V}$. Treatment with

\section{TABLE V}

Frequency of Splenectomy in Thalassaemic Children in Relation to Presence or Absence of $A u(1)$ Antigen or Anti-Au(1) Antibodies

\begin{tabular}{l|c|c|c}
\hline \multicolumn{1}{c|}{ Patients } & No. & Splenectomy & $\%$ \\
\hline With Au(1) & 18 & 9 & 50 \\
With anti-Au(1) & 35 & 25 & 71 \\
$\begin{array}{l}\text { Without Au(1) or } \\
\text { anti-Au(1) }\end{array}$ & 116 & 53 & 46 \\
\hline
\end{tabular}

Comparison of patients with $\mathrm{Au}(1)$ or anti-Au(1) vs. those with neither antigen nor antibody.

$$
\chi^{2}=7 \cdot 149, \text { p. }<0.05 \text {. }
$$

splenectomy was most frequent in patients with anti-Au(1) and was more common in patients with $\mathrm{Au}(1)$ or anti-Au(1) than in the remaining patients with neither the antigen nor the antibody and the difference is significant $\left(\chi^{2}=7 \cdot 149\right.$, d.f. $=2$,

TABLE IV

Mortality Rate in Thalassaemic Patients Observed Over a 5-year Period

\begin{tabular}{|c|c|c|c|c|c|}
\hline Patients & No. & Dead & $\%$ & $\begin{array}{l}\text { Median Age } \\
\text { at Death } \\
(y \mathbf{r})\end{array}$ & $\begin{array}{l}\text { Age at Death } \\
\text { Range } \\
(y r)\end{array}$ \\
\hline $\begin{array}{l}\text { With } \mathrm{Au}(1) \\
\text { With anti-Au(1) } \\
\text { Without } \mathrm{Au}(1) \text { or anti-Au(1) }[\mathrm{Au}(0)]\end{array}$ & $\begin{array}{r}18 \\
35 \\
116\end{array}$ & $\begin{array}{r}4 \\
4 \\
11\end{array}$ & $\begin{array}{r}22 \cdot 2 \\
11 \cdot 4 \\
9 \cdot 5\end{array}$ & $\begin{array}{r}5 \cdot 0 \\
10 \cdot 5 \\
7 \cdot 0\end{array}$ & $\begin{array}{l}(4-6) \\
(8-16) \\
(1-12)\end{array}$ \\
\hline
\end{tabular}

$\mathrm{Au}(1)$ vs. anti-Au(1)

$\mathrm{Au}(1)$ vs. $\mathrm{Au}(0)$

$\mathrm{Anti}-\mathrm{Au}(1)$ vs. $\mathrm{Au}(0)$
P (Mann-Whitney)

$0 \cdot 014$

$0 \cdot 114$

$0 \cdot 086$ 
$P<0.05)$. However, splenectomy was performed in many instances after antibody was already present and, in general, on older children.

Immunoglobulins. Children with $\mathrm{Au}(1)$ or anti-Au(1) had significantly lower IgG immunoglobulin levels than those with neither antigen nor antibody. IgA levels were significantly lower in those with antigen than with antibody. No other significant differences were found, but levels of all immunoglobulins were slightly lower in those with $\mathrm{Au}(1)$ than with anti-Au(1) (Table VI).

\section{Discussion}

Patients with thalassaemia are subjected to repeated exposure to Australia antigen as a consequence of repeated blood transfusions. We have observed persistent antigen and antibody in them. We have not studied antigen/antibody complexes since the methods hitherto available for this measurement are either insensitive or indirect. The recent development by Coller et al. (1971) of a highly sensitive radioimmunoassay coprecipitation method which can apparently detect antigen/antibody complexes will now permit the biological study of significance of this reaction.

The frequency of $\mathrm{Au}(1)$ is relatively high in this thalassaemia patient group $(10 \cdot 6 \%)$, but not significantly higher $\left(x^{2}=2 \cdot 445, \mathrm{P}<0 \cdot 10\right)$ than that reported for American thalassaemia patients (Blumberg et al., 1965) from whom only single or small numbers of sera from each individual were tested. The antigen once present in these patients is nearly always persistent; there were only two inconsistencies in 61 patient years. The results are similar to those previously reported for apparently asymptomatic individuals living in Rongelap (Blumberg et al., 1966), Down's syndrome patients (London et al., 1969), lepromatous leprosy patients living in Cebu (Blumberg and Melartin, 1970), and leukaemia patients (Sutnick et al., 1970).

The persistence of $\mathrm{Au}(1)$ antigen in these patients contrasts with the situation in acute viral hepatitis in which the presence of the antigen is transient and may persist for only days or weeks (London et al., 1969; Shulman and Barker, 1969). We have made the hypothesis that the persistence of the antigen is related to an immune impairment present in some patients (i.e. Down's syndrome, leukaemia) which may be associated with cellular immunity (Blumberg et al., 1970c). It is not known if the persistence is due to recurrent infection of patients living in an environment where they are continually exposed to 'infection' with Australia antigen, or to the persistence of a single infection. Since these thalassaemic patients are transfused repeatedly they are continually re-exposed to the infection, and hence it is not possible to distinguish reinfection from persistent infection from these data.

The frequency of anti-Au(1) is very high in the patients reported here $(20.7 \%)$. In thalassaemia patients transfused in Greece it is still higher (40.2\%) (Edonomidou et al., 1970), which might be due to a higher frequency of $\mathrm{Au}(1)$ among Greek blood donors than among Italian donors. Anti-Au(1) is sometimes persistent but less so than the antigen (Fig. 2). Individuals who develop persistent antibody are distinct from those who develop persistent antigen; that is, the ability to form antibody or antigen appears to be an inherent quality of the individual.

There are other characteristics that can define the differences between individuals who form persistent antibody, and those who develop persistent antigen. Males have a higher frequency of Australia antigen and females have a higher frequency of antibodies. The former observation is

\section{TABLE VI}

Comparison of Immunoglobulins in Respect of Australia Antigen and Antibody in Thalassaemia Patients (Wilcoxon Matched Pair Signed Ranks Test) (Mean Values Shown in $\mathrm{mg} / \mathrm{ml}$ )

\begin{tabular}{|c|c|c|c|c|c|c|c|}
\hline & $\underset{(\mathrm{mg} / \mathrm{ml})}{\mathrm{IgG}}$ & $\mathbf{P}$ & $\begin{array}{c}\mathrm{IgM} \\
(\mathrm{mg} / \mathrm{ml})\end{array}$ & $\mathbf{P}$ & $\underset{(\mathrm{mg} / \mathrm{ml})}{\mathrm{IgA}}$ & $\mathbf{P}$ & $\begin{array}{r}\mathrm{IgD} \\
(\mathrm{mg} / \mathrm{ml})\end{array}$ \\
\hline $\begin{array}{l}\text { Au(1) } \\
\text { Anti-Au(1) }\end{array}$ & $\begin{array}{l}13 \cdot 7 \\
16 \cdot 9\end{array}$ & & $\begin{array}{l}1 \cdot 27 \\
1 \cdot 62\end{array}$ & & $\begin{array}{l}1 \cdot 54 \\
2 \cdot 19\end{array}$ & $<0.05$ & $\begin{array}{l}0 \cdot 078 \\
0 \cdot 158\end{array}$ \\
\hline $\begin{array}{l}\mathrm{Au}(1) \\
\mathrm{Au}(0)^{\star}\end{array}$ & $\begin{array}{l}13 \cdot 7 \\
20 \cdot 0\end{array}$ & $<0.01$ & $\begin{array}{l}1 \cdot 27 \\
1 \cdot 58\end{array}$ & & $\begin{array}{l}1 \cdot 54 \\
2 \cdot 40\end{array}$ & & $\begin{array}{l}0.078 \\
0.0195\end{array}$ \\
\hline
\end{tabular}

$\star \mathrm{Au}(0)=$ patients without Australia antigen or antibody. 
consistent with our earlier observations that $\mathrm{Au}(1)$ is more common in males than in females in 22 of 23 populations studied (London et al., 1969; Sutnick et al., 1968; Blumberg et al., 1970b; Blumberg et al., 1972). The higher frequency of antibody in females has not been observed previously. Persistent antigen is more common among the younger patients, confirming our earlier observations in other populations (Blumberg, Sutnick, and London, 1968; Blumberg et al., 1970c). Persistent antibody is commoner in older patients; this has not been studied previously.

The decreased immunoglobulin values may be related in part to the high frequency of splenectomy. We plan to test the hypothesis that transfused patients with thalassaemia may develop antigen/ antibody complexes, and the decreased levels of immunoglobulin could be associated with this.

We had previously reported (Vierucci et al., 1968) that the formation of anti-Ag (lipoprotein) antibodies contribute to the mortality in thalassaemic children. The increased mortality among the patients with Australia antigen is small and should be confirmed, but its validity is supported by the increased survival of the patients with anti-Au(1). If it is sustained, then we have identified a second factor which contributes to early mortality in thalassaemic children.

We thank Professor M. Ortolani, Director of the Centro della Microcitemia of Ferrara, for helpful co-operation, Miss M. Lorenzini for technical assistance, and Dr. Samuel Litwin of The Institute for Cancer Research for assistance with the statistical analysis.

\section{REFERENCES}

Blumberg, B. S. (1964). Polymorphisms of the serum proteins and the development of iso-precipitins in transfused patients. Bulletin of the New York Academy of Medicine, 40, 377.

Blumberg, B. S., Alter, H. J., and Visnich, S. (1965). A 'new' antigen in leukemia sera. Fournal of the American Medical Association, 191, 541 .

Blumberg, B. S., Byrne, R. J., Chanock, R. M., Cockburn, W. C., Kono, Y., Koza, J., McCollum, R. W., Ménaché, D., Penttinin, K., Purcell, R. H., Taylor, P. E., Wewalka, F. G., and Zuckerman, A. J. (1970a). Viral hepatitis and tests for the Australia (hepatitis-associated) antigen and antibody. Bulletin of the World Health Organization, 42, 957.

Blumberg, B. S., Gerstley, B. J. S., Sutnick, A. I., Millman, I., and London, W. T. (1970b). Australia antigen, hepatitis virus and Down's syndrome. Annals of the New York Academy of Sciences, 171, 486.

Blumberg, B. S., and Melartin, L. (1970). Australia antigen and hepatitis: studies in asymptomatic people and lepromatous leprosy patients. Archives of Internal Medicine, 125, 287.

Blumberg, B. S., Melartin, L., Guinto, R. A., and Werner, B. (1966). Family studies of a human serum isoantigen system (Australia antigen). American fournal of Human Genetics, 18, 594.

Blumberg, B. S., Sutnick, A. I., and London, W. T. (1968). Hepatitis and leukemia: their relation to Australia antigen. Bulletin of the New York Academy of Medicine, 44, 1566.
Blumberg, B. S., Sutnick, A. I., and London, W. T. (1970c). Australia antigen as a hepatitis virus: variation in host response. American Fournal of Medicine, 48, 1.

Blumberg, B. S., Sutnick, A. I., London, W. T., and Melartin, L. (1972). Sex distribution of Australia antigen. Archives of Internal Medicine, 130, 227.

Ceppellini, R., Bedarida, G., Carbonara, A. O., Trinchieri, G., and Fillippi, G. (1970). High frequency and family clustering of $\mathrm{Au}$ antigen in some Italian populations. Edizioni Minerva Medica, Atti Convegni Farmitalia 'Antigene Australia ed Epatite Virale', Milan, February 7, p. 53.

Coller, J. A., Millman, I., Halbherr, T. C., and Blumberg, B. S. (1971). Radioimmunoprecipitation assay for Australia antigen, antibody, and antigen-antibody complexes. Proceedings of the Society for Experimental Biology and Medicine, 138, 249.

Edonomidou, J., Costantoulakis, M., Augostaki, G., Taylor, P. E., Zukerman, A. J., Baines, P. M., and Bryceson, M. A. (1970). The incidence of hepatitis-associated antigen and antibody in patients with thalassemia in Greece. XIIIth Congress of Haematology, Munich, August, 1970.

Gerin, J. L., Purcell, R. H., Hoggan, M. D., Holland, P. V., and Chanock, R. M. (1969). Biophysical properties of Australia antigen. Fournal of Virology, 4, 763.

Gocke, D. J., Greenberg, H. B., and Kavey, N. B. (1970). Correlation of Australia antigen with posttransfusion hepatitis. Fournal of the American Medical Association, 212, 877.

Goeser, E., London, T., Sutnick, A., Blumberg, B., and Senior, J. (1970). Posttransfusion hepatitis and frequency of donor blood Australia antigen in population sub-groups. Clinical Research, 18, 380.

Goldfield, M. (1970). Progress report on hepatitis studies in New Jersey. Presented at 3rd Annual Meeting, Society of Epidemiologic Research, Minneapolis, Minnesota, fune.

Lang, N. (1966). The overtaking of reaction electrophoresis as a quantitative immunological method. Protides of Biological Fluids, 14, 517.

London, W. T., Sutnick, A. I., and Blumberg, B. S. (1969). Australia antigen and acute viral hepatitis. Annals of Internal Medicine, 70, 55.

Mancini, G., Carbonara, A. O., and Heremans, J. F. (1965). Immunochemical quantitation of antigens by single radial immunodiffusion. Immunochemistry, 2, 235.

Okochi, K., Murakami, S., Ninomiya, K., and Kaneko, M. (1970) Australia antigen transfusion and hepatitis. Vox Sanguinis, $18,289$.

Piazzi, S. E. (1969). A simple method for preliminary immunodiffusion test of antigen-antibody system having unknown ratios of reaction. Analytical Biochemistry, 28, 281.

Shulman, N. R., and Barker, L. F. (1969). Virus-like antigen, antibody, and antigen-antibody complexes in hepatitis measured by complement fixation. Science, 165, 304.

Shulman, N. R., Hirschman, R. J., and Barker, L. F. (1970). Viral hepatitis. Annals of Internal Medicine, 72, 257.

Siegel, S. (1956). Nonparametric Statistics for the Behavioral Sciences, p. 116. McGraw-Hill, New York.

Sutnick, A. I., London, W. T., and Blumberg, B. S. (1967). Australia antigen, Down's syndrome, and hepatitis. (Abst.) Fournal of Clinical Investigation, 46, 1122.

Sutnick, A. I., London, W. T., Blumberg, B. S., Yankee, R. A., Gerstley, B. J. S., and Millman, I. (1970). Australia antigen (a hepatitis-associated antigen) in leukemia. Fournal of the National Cancer Institute, 44, 1241.

Sutnick, A. I., London, W. T., Gerstley, B. J. S., Cronlund, M. M., and Blumberg, B. S. (1968). Anicteric hepatitis associated with Australia antigen: occurrence in patients with Down's syndrome. Fournal of the American Medical Association, 205, 670.

Vierucci, A., Blumberg, B. S., Dettori, M., Borgatti, L., and Levene, C. (1968). Isoantibodies to inherited types of $\beta$-lipoproteins (Ag) and immunoglobulins (Gm and Inv). Fournal of Pediatrics, 72, 776 .

Correspondence to Dr. A. I. Sutnick, Institute for Cancer Research, 7701 Burholme Avenue, Philadelphia, Pennyslvania 19111, U.S.A. 